学

\title{
第45回青森県地方部会
}

昭和62年 3 月15日（日）ー八戸パークホテル

耳鼻咽喉科・頭顓部外科領域における latamoxef (LMOX) の組織内濃度の検討

○神均・朴沢二郎・斉藤久樹・北山裕隆 (弘前大)

今回, 弘前大学病院耳鼻咽喉科において $\mathrm{LMOX} / 1 \mathrm{~g}$ (または $2 \mathrm{~g}$ ) 点滴静注後の血中濃度および組織内濃度 を測定・検討した。最高濃度到達時間は血中が点摘終 了時であるのに対し組織内では0.5〜1.5時間と遅れを 示した。 また, その時間帯の組織移行を血中濃度に対 する組織内膿度の比率でみると頸部皮雐>舌>唾液 腺 >鼻茸 $\fallingdotseq$ 鼻・副鼻腔粘膜 $>$ 扁桃>頸部脂肪の順であ った.

\section{末梢性めまい症例に対するVinpocetine の使用経験}

○西山 勉・朴沢二郎・鎌田重輝・石川 警 (弘前大)

弘前大学病院耳鼻咽喉科めまい外来に打いて各種め まい疾患に対し, Vinpocetine 在投与し，自覚症状，他 賞所見の推移を観察したところ, 自覚症状では, 回転 感, 立ちくらみ, 頭痛, 悪心・嘔吐などの改善率が高 く，頭位眼振は，15例に認められたものの，麻痺性， 刺激性眼振のいずれにも改善がみられた，前庭障害の 程度 CP (\%) と自覚症状の改善度には相関はなかっ た。また，本剤の投与中，その経過を回転検査に上り 経時的に観察したメ二エール病 2 例を供覧した。

質問 菊池和彦 (青森労災)。発作時にも有効加。応 答 急性期には，メイロン静注を併用した。

$$
\text { コンピューター回転検查 }
$$

\section{-2 種の回転方式の比較検討（第 2 報）-}

○一條宏明・朴沢二郎・鎌田重輝・藤原文明

西村哲也（弘前大）

末梢前庭障害例 84 例に台形回転方式と正弦波回転方 式によるコンピューター回転検査を施行し以下の結果 を得た，1）患側迷路優位性の検出には台形回転方式 の方が有力であった２）VOR-gain の小さな例では 台形回転方式での左右差の検出は困難であった３）
頭位眼振やめまいの自覚のある時期，あるいは健側迷 路優位性を呈する時期では両者の一致率が高かった。 4) 頭位眼振やめまいの自覚がない時期では両者とも 正常なことが多かった。

第 V，VII，VIII脳神経血管減荷術における

手術前後 ABR の变化

中村清純（十和田市立）

近年, 脳神経外科において, 顔面痙攣, 三叉神経痛, 耳鳴に対して，血管減荷術が施行されている.この手 術前後の $\mathrm{ABR}$ 変化を記録した結果, 以下のことが推 察された。1. 隇荷手術により聴力障害が発生すること がある.2. ABRのI-V波間隔の延長は，三叉神経血 管隇荷術の方が顔面神経血管滅荷術より出現率が多 く，手術手技同様，脳幹に対する影響が大きいものと 思われた.3.これらの手術後聴力障害が出現しなくて も, 脳幹には軽度障害が生じている可能性がある. 質問 福滆敬二(弘前大). I - V 波の延長について, 術後, 時間が経過した場合, 延長はそのままの状態で 推移するのか，元に戻るのか。応答 遠くから来 ている症例が多く，長期間の経過観察が不可能な状態 である。また I-V波間の回復はあまりないと思う。 質問 石田 孝(青森県病). 術中モニター成績につい て, 小脳の圧排は何分位行うとV波の潜時の延長か認 められるか。応答 10 分位と思われるが, 現場に いないのでよくわからない。ただ10分の間ずっと圧排 しつづけているわけではない。質問・追加佐々 木均（弘前大）。1）手術手技等に上り，耳鳴・難聴の 発生率に差があると思われるが.2）手術後の $\mathrm{ABR} の$ 潜時延長例のうち，経過観察中に潜時延長が回復して くる例と回復しない例があるが. 3) VI, VII神経血管減 荷術の合併症として, 耳鳴が報告されているのに, 耳 鳴に対しVIII神経血管減荷術を施行する理由. 応答 術式による耳鳴の発生の差異はあると思う。また当科 には耳鳴が術後発生した症例は少ない。追加菊 池和彦(青森労炎)。耳鳴に対して手術を受けた患者が 後日当院を受診した. 耳鳴増悪, 難聴を強く訴えてい 
た。質問 朴沢二郎(弘前大)。術式によってもか なり影響の差があると思うが，特に小脳の圧排の程度 による影響はどうか。応答 術式に関して小脳の 圧排による影響もかなりあるものと思わ机るが，術式 に関しては，その法により差異があるのではないかと 思われる。

\section{化学療法の奏効した副鼻腔㵦外性形質細}

\section{胞腫の 1 例}

○西村哲也 ・上村敏夫・田沢正之（弘前大）

1. 昭和61年11月に大館市立病院耳鼻科を受診した 73歳男性の IgA $\lambda$ 型副鼻腔形質細胞腫を報告した。 2 . 本症例は化学療法（メルファラン，プレドニゾロンに よるMP 療法) を行い, 腫㾤の著明な縮小効果がみら れた.3. 髄外性形質細胞腫の手術困難な症例に対して は積極的に化学療法を適用していくべきと考えた。

質問 神均(弘前大). 患者の蛋白分画や免疫等の 経過はどうであったか．応答 蛋白分画の変化は $\alpha_{2}$-gl.のみ増加して, いわゆる慢性炎症所見を呈して いるのみであった.グロブりン分画は IgA 等大きな変 動はなかった。質問 福岡敬二(弘前大)。1）メ ルファランの投与経路について.2）前頭洞の陰影は腫 瘍と考えるか, 炎症と考元るか. 3) steroidは, 現在も 続けているのか. 応答 1) メルファランは内服. 2）上顎洞以外の陰影増強もあり，炎症ではなく腫瘍で あると考えられた.3）プレドニゾロン使用は副作用が 出た時点で漸減ないしは中止を考える。質問 褡 田 勝(八戸市民)。本例の視力障害の有無について。 応答 当初眼球突出を認めたが視力障害はなかった. 追加 斉藤久樹 (弘前大)。放射線にMP 療法を併用 し, 経過良好として本学会で報告した 1 例が, 術後数 年を経て他部位に転移をみたので追加した。

\section{弘前大学耳鼻咽喉科学教室における喉頭}

癌治療の現況（昭和 56 ～61年）

○福士栄治・朴沢二郎・齐藤久樹・盛 侓

福岡敬二・太田修司（弘前大）

今回我々は昭和 56 年から昭和 61 年にかけて当科を受 診し,诶頭癌の診断をうけ入院治療を行った患者106症 例について, 年齢分布, 病型分類, 病期 (進行度), 治 療法を調查し分析を行った。質問 神均（弘 前大)。喉頭癌に対してのシスプラチン単独投与におけ る有効性, 再発性はどうか。応答 シスブラチン は未治療の例に関しては減量効果が期待できるが, 再 発例や術後の効果はあまり期待できない印象を持って いる。質問 石田 孝(青森県病)。喉頭マイクロ
下に生検を行っている症例も多いようだが，同時にレ ーザーに上る焼灼は行わないのか。応答 レーザ 一切除施行した例は106例中 2 例あり，いずれも切徐後 放射線療法を行いその後マイク口で悪性 (一) の結果 を得た。質問 袴田 勝 (八戸市民)，1）術前の 化学療法の種類とその効果について.2）診断から手術 療法などの期間。応答 UFT 等を術前に投与開 始している例がほとんどであるが，すぐ手術してしま うことが多く，腫場に対する隇量効果は判定できない 状況である。応答 盛庸. 最近は喉頭マイク 口下に進展度検査と同時に生㭘を行う症例が増之てお り,生検後 1 週間で晿頭全摘出を施行する場合が多い. 応答 斉藤久樹，基礎的な検討であるが，頭頸部癌を ヌードマウスに移植してUFTを経口投与した治療実 験では，腫浧增殖抑制刘果をみるも，腫湯の縮小，消 失はみなかった。

\section{悪性腫瘍を疑わせた巨大な濾胞性歯牙の}

胞の 1 症例

○池野敬一・藤原文明（弘前大）

袴田＼cjkstart勝（八戸市民）袴田真理子（五戸町立）

西村哲郎 (八戸市)

骨破壞を伴う濾胞性歯牙のう胞症例を経験した。の う胞は右上頡骨内埋没歯上り発生しており，上顎洞粘 膜は上方に圧排され残存していた。のう胞内容は槳液 性無菌性の膿汁であった。 Luc-Caldwell の手術にて のう胞は摘出可能であり, 病理学的に異型性は認めら れなかった。質問 中村清純(十和田市立)，1）内 容液の組成は.2）アンギオの施行の有無。応答 1）内容物は細胞, 細菌はマイナスで生化学は血液像に 類似していた。 2) アンギオは施行していない。質 問 朴沢二郎(弘前大)。報告を聞いていると， 万胞性 歯牙のう胞である。最近は余り見ないが, 演題名も上 顎のう胞でなく歯牙のう胞とした方がよいのではない か. 応答 演題訂正する。

\section{迷路梅毒症例の治療について}

○上村敏夫（大館市立）

田沢正之・西村哲也 (弘前大)

迷路梅烮の診断の得られた 4 例について, 難聴増悪 時, めまい発作時にペニシリンによる駆梅療法及びス テロイド投与を行い,その効果について検討を行った。 その結果, 駆梅療法のみでは聴力の改善, めまいの改 善は認めないものの, ステロイドを併用した症例（の ベ 4 例)では 2 例 (50\%)に 5 周波平均で $10 \sim 20 \mathrm{~dB}$ の 恥力改善を認めた。この有効であった 2 例の主訴が難 
聴の増悪であったことから，難聴の増悪時にはステロ イド剤の併用が有効であると考えられた。 質問 石田 孝(青森県病)。迷路梅毒と診断された根拠につ いて. 前庭症状が強く, 蛤牛症状が軽い根拠は何か. 側頭骨病理所見と合致しないものと思われる。応 答 診断に際しては実質性角膜炎等強く, 先天性梅毒 による難聴であろうと考えられる症例のみに限定した が絶対的とは言えない，質問 中村清純（十和田 市立)、ステロイドの使用に関して他に突発性難聴に準 じた治療はしないのか。応答 今回は検討してい ないが，今後の課題としたい，質問 神均(弘 前大)。梅毒の病期分類と迷路梅毒の発生期と治療の関 係は。応答 今回は先天性梅毒と考えられ症例に 限ったので病期分類はできない.

当科におけるアレルギー性鼻炎の現況

○石田 孝・宮野和夫・円山宏洋（青森県病）

昭和 60 年 1 月から 61 年 12 月まで, 青森県立中央病院 耳鼻咽喉科を受診し，アレルギ一性鼻炎（血管運動性 鼻炎も含む）と診断された287例について検討を行っ た，男女比は 1：1で，通年性と季節性との比は2.5： 1 であった，月別では 6 月から10月に多く，特に 9 月 に多かった，季節性についてみると， $3 ， 4$ 月のスギ は少なく，9月のヨモギが多く，次いで6月のイネ科 が多かった。質問 永井政男(弘前大). 9 月のヨ モギ花粉症が非常に多いようであるが，他の因子は関 係していないのか。応答 アレルギー性鼻炎を疑 うかどうかでデー夕はかなり異なるものと思うが，青 森地区ではスギ花粉症は少ないものと思われる。

\section{八戸地方における花粉症の検討}

\section{第 2 報 1986年空中花粉浮遊成績}

○袴田 勝 (八戸市民) 袴田真理子（五戸総合）

八戸地方に㧈ける花粉症の基礎調査として，八戸市 根城地区にて，空中花粉浮遊調査を行った。1986年の 花粉浮遊期間は273日間 ( 3 月21日一-12月18日) で, 花 粉総数は 17,783 個 $/ \mathrm{cm}^{2}, \mathrm{~J}$ 日平均花粉数は65.14個/ $\mathrm{cm}^{2}$ であり，5月31日に最高花粉浮遊 (2412個) を記録 した。当地の花粉浮遊は tree season ( 3 月下旬一 6 月 下旬), grass season ( 5 月中旬一 10 月初旬), weed season（8月下旬一 10 月上旬）の 3 期に分かれ，25種 の空中花粉が確認され,花粉カレンダーの作成をみた。 これは，花粉抗原検索の一助になるものと思われた。
質問 永井政男 (弘前大). サクラの木は観測点から何 mの地点にあったか。応答 調查場所とサクラの 植生の距離は約 $10 \mathrm{~m}$ である。

アクリジン・オレンジ染色による核酸の観察

○今 一郎 (青森市) 蝦名 博（青森市民）

上頻洞粘膜の腺細胞及び分泌物をアクリジン・オレ ンジ染色し，落射蛍光顕微鏡で観察した。粘膜はカル ノア液で固定, 厚さ $3.5 \mu$ の切片を作り，0.01\%アクリ ジン・オレンジ液で室温で10分間染色, リンゲル液で 封入した、観察は $\mathrm{B}$ 励起, 励起補助フィルターは $\mathrm{EY}$ 455，吸収フィルターは0.515で行った。腺細胞の核は 緑色, 細胞質の核周囲の部分は赤色, 分泌顆粒は緑色 の蛍光を示した，腺細胞の活動状態により，蛍光の強 さが異なり, 特に休止期と思われる細胞では, 赤色虽 光が強い傾向が認められた。

学位論文 (学位授与者研究発表)

トンネルエ事従事者の騒音性難聴に関する研究

(1)その生龍について

(2) その経年変化について

円山宏洋（青森県立中央）

リンゴ花粉症における血清学的研究

一特に Radioallergosorbent test

(RAST)による特異的 $\operatorname{IgE}$ 抗体の検討一 永井政男（弘前大）

等加速度回転刺激負荷時の前庭神経核及 び小脳における糖消費量の变化に関する オートラジオグラフィーを用いた研究

一特に左右前庭神経核間の差について一

盛庸（弘前大）

一側性末梢前庭障害者の重心動摇検查成

績に関する研究

一特に種々の眼振発現時期における重心

動摇の特徵についてー

太田修司（弘前大）

カリウムイオン内耳内導入の迷路組織並 びに機能に及ぼす影響に関する研究 福岡敬二（弘前大）

帰朝報告

ベイラー医科大学に留学して 宇佐美真一（弘前大） 


\section{第70回福岡県地方部会}

\section{昭和62年 4 月11日（土）一産業医大ラマツィーニホール}

\section{難聴を伴う De Sanctis Cacchione 症候群の 1 例}

○吉峯晃一・江浦陽一・曽田豊二（福岡大）

満留昭久 (同・小児科)

色索性乾皮症に知能低下, 進行性の感音難聴他に多 彩な神経症状を伴ったDe Sanctis Cacchione 症候群 の一例を経験したので報告した．初診時，6歳女児， 日光露出部に色素沈着が著明であり, 純音聴力では中 等度の感音難聴があった。 6 年後には高度感音難聴を 呈し CT scan では頭蓋骨は小さく，骨壁は肥厚，巨大 な前頭洞，側頭葉の萎縮が著明であった。発生機構は エンドヌクレアーゼの欠損によるDNA の部分的修復 障害であった。この症例の病型分類は $\mathrm{A}$ 群を示し UV 生存率は $5 \%$ 以下であった。進行性の難聴の原因は, 側 頭葉の萎縮, 聴神経の軸索変性, 髄䩗の障害などが考 えられている，A群は特に神経症状が著明で進行性の 難聴をほとんどに認めるが， B 群〜 G 群までの難聴に ついての報告はまれであり，今後その解明が必要と思 われる。質問 牧嶋和見 (九大)。1）この症候群 の神経症状のうち難聴の頻度は。2) Kaposi's dermatitis との関係は如何. 応答 1) 難聴はほとんど すべての例に認められる，約 $90 \%$ と思われる。A群以 外のB群〜 G 群では難聴は軽度になると思われる。2) Kaposi が1874年に報告し, 次いでDe Sanctis とCacchéone が兄弟例を報告している，同椂の症候群であ る.

\section{頭振を負荷した足踏み検査の有用性}

○久冨圭子・伊藤信輔・井上 望・山口勝矢 平野実 (久留米大)

福田の足踏み㭘查は, 能動的な運動の中に左右迷路 機能の不均衡を検出する優れた方法であるが，これを より鋭敏にする目的で，頭振を負荷する方法を考案し た.12例の急性一側性前庭障害の経過を観察した結果， 足踏み検查で異常を示さないまでに回復した時期に, 頭振を負荷した足踏み検査を行うと, 依然明らかな平 衡失調が出現することを認めた。方法は，水平に約 $90^{\circ}$ ， 1 秒 1 往復の速さで 7 回の頭振を行った直後に, 足踏 みを命じる。この方法により，従来の検查では検出し 難い潜在性の迷路機能の不均衡をとらえることができ る. 質問 野上兼市郎 (九大). ENG下に眼振を チェックしたか.フレンッェル眼鏡下では眼振の把握
には不十分と思うが.急に頭を振った際のフラッキは, 頭振後のフラツキとは異なると思うが. 応答 今 回述べたのは，前庭眼反射ではなく，脊䯣反射の異常 による症状を客観的にとらえる方法である。眼振は， フレンツエルで観察した。質問 安田宏一（浜の 町病院).せっかく内耳の興筬性が扔さまって来ている のに, 頭振りをして再び興奮をさせるのは, 治療の経 過としては良くないのではないか. 骎た子を起こして いることにならないか。応答 頭振によって迷路 に加わる刺激の強さは, 日常生活で経験する程度のも のと考えられ，すでに社会復㷌をしている患者の症例 が，この検査により悪化するとは，考えられない。

質問 調 重昭(福岡大). 頭振の具体的な方法と足踏 検査をはじめる時期についてききたい。また健康者の 基準は如何. 応答 1 秒 1 往復, 水平約 $90^{\circ}$ で 7 回 の頭振を行い直後に足踏みをさせた.

回転刺激による一側高度前庭機能低下症 例の経過観察

○过田直隆・河野正司 - 白石君男 ・ 調 重昭 (福岡大)

回転検査の診断的意義や患側決定に関する有用性の 評価は高くない現状である．今回われわれは健康者の 回転眼振反応の各パラメータをあえて massとしてと らえ, 一側高度障害のめまい症例との相違などを再検 討した。 $0.5^{\circ}$ 加速・ $30^{\circ}$ 回転と $1^{\circ}$ 加速・ $60^{\circ}$ 回転法の回 転検查の実用性を模索してみると，パラメータとして は眼振強度を多面的に検討する必要があることがわか つた。めまい症例では経過をみたり，温度検査などの 他の検査と対比させればある程度障害部位や予後の判 定に役立つといえる。質問 上村卓也(九大). 回 転方向によって, 眼振の持続時間等の, 左右差が出る が, 出る側と, 出ない側が半数ずつあるので,この方 法は問題があるのではないかという発表だったが、こ れはむしろ予測されているのではないか。応答 一側障害例で左右差が出るということは, 以前からわ かっていたが, 今回もう一度, mass としてとらえた場 合何か新しいことが出てくるのではないかと思って行 った.

GM 鼓室注入法によるメニエール病の治 療一続報一 
○内 義輝・野上兼市郎・井上裕章・西平 修 上村卓也（九大）

我々は, 第 9 回北部九州連合会にて, メニエール病 難治例 2 例のゲンタマイシン (GM) の鼓室内注入潦法 (Lange 1979) を報告した。この3 例共治療後めまい発 作は軽快したが，迷路機能がほとんどまたは完全消失 し, 治療後しばらく体の浮動感自覚した。今回, 迷 路機能消失を起こさないこと目的として，メニエー 儿病 3 例に対し, GM 少量鼓室内注入治療を行った. 注入総量は予め $24 \mathrm{mg}$ と決め, 1 回 $4 \mathrm{mg} 1$ 日 2 回注入 した。症例 $1 ， 32$ 歳男性, 観察期間 1 年 7 力月, 迷路 機能軽度 $\mathrm{CP} \rightarrow$ 中等度 $\mathrm{CP}$, 平均発作間隔 5 日 $\rightarrow$ 治療後 は 1 回の発作のみ。症例 2,56 歳女性, 観察期間 5 力 月, 迷路機能正常 $\rightarrow$ 軽度 $\mathrm{CP}$, 発作間隔15日 $\rightarrow$ 治療後月 1 回程度の小発作のみ. 症例 3,55歳男性, 観察期間 3 力月, 迷路機能軽度 $\mathrm{CP} \rightarrow$ 消失, 治療後発作なし. 3 例共, 平均聴力は治療前後で変化なく, 治療後浮動感 なし、GM 少量注入法は迷路機能低下は軽度ながら， めまい発作を押さえることが可能であった。質問 調 重昭(福岡大)。もともと患側聴力の程度は. 嘔 吐感, 頭痛などの小発作からも解放されたか. 軽度前 庭障害を起こしてメマイが治るというメカニズムにつ いて。応答 聴力は症例 1 が $51 \mathrm{~dB}$, 症例 2 が $50 \mathrm{~dB}$, 症例 3 が $65 \mathrm{~dB}$ であった. 頭痛などの症状はな かった、GM が前庭の irritability を抑えたのであろう が機序は不明である。質問 伊藤信輔 (久留米大). 1）温度反応の低下の度合いと治療効果は関連してい るか. 2) 脱落症状が残る心配はないか。応答 力 ロリックテストの変化の程度による改善の度合いの差 は認められなかった。脱落症状は今回の報告例にはな かった。

\section{ネコ喉頭内の中頸神経節由来の交感神経}

線維の分布について

○斉藤龍也・吉田義一・田中康政・金関 毅 平野 実 (久留米大)

WGA-HRP 順行性軸索輪送法を用いて, ネコの喉 頭咽頭における中形神経節由来の交感神経節後線維の 分布を検討した。結果は以下のごとくであった.1. 中 頸神経節由来の交感神経節後線維は, 声門下, 被翌軟 骨尾側端の高さから，ほほ第 4 気管輪の高さの喉頭に 分布していた. 2.末梢の標識線維は, 腺組織周囲, 血 管周囲に分布していた. 3. 中頸神経節由来の交感神経 節後線維は, 交感神経本幹, 上頸神経節, 上喉頭神経 内枝を経由して喉頭に分布していた.4.上喉頭神経外
枝，下喉頭神経，上喉頭動脈，下喉頭動脈との関連は 見いだせなかった，以上を前回報告の上頸神経節由来 の交感神経節後線維の分布と合わせて検討した。なお， 喉頭蓋を含めた上部声門の交感神経節後線維がどの神 経節に由来するかは,今後の課題とした。質問 曾 田豊二(福岡大)。神経の取り込みのParticle はどれく らいの大きさで，どういうふうにしてとり込んで行く のか. 応答 中頸神経節に注入したWGA-HRP は, 中頸神経節に胞体をもつ神経細胞にとり込まれ, 通過線維からはとり込まれない。また血管周囲腺房周 囲の標識線維を確認することで上頸神経節の支配領域 との違いを検討できる。

嚥下機能検査における欌下圧測定の意義

○小宮山荘太郎・笠 誠一・山下弘之・宮崎 洋 (九大)

嚥下圧測定装置を開発し，咽頭及び頸部食道の德下 時圧波形（嚥下圧）を観察した。その結果，嶼下圧波 形は各咽頭の部位で特異的であり, 病的症例では波形 がくずれる。压は中咽頭, 下咽頭, 頸部食道にピーク をもち 3 峰性を示した。また, 部分的圧低下型と全般 的圧低下型に分類できることが分かった，睘下圧の伝 搬速度を測定してみると, 中咽頭が最も速く，しかも， 各部位によってその速度が異なることも判明した。矒 下運動と呼吸運動との関連を噯下呼吸と呼ぶと, 噯下 運動は呼気相に惹起され，しかも曖下後も呼気になる 比率が高い $(90 \%)$ 。しかし, 誤䁍を訴える症例は, 嬩 下後呼気を行う症例が多いことが判明した，曣下障害 を手術的に治療しようと思う時は, 䁩下圧測定が必須 のものと考えられた。また，リハビリを行う際は，呼

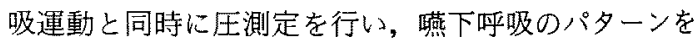
知る必要がある。質問 吉田義一(久留米大)。1) 喉頭挙上との関連について教示を.2）一側性と両側性 咽頭麻盘の違いが出るか. 応答 1）喉頭挙上の程 度を簡単に測定する方法を知らない.2)一側性麻盘と 両側性麻痺では，圧波形の形のみだれと圧低下の差と なって観察される。筫問 大久保 洋(久留米大)。 1）アカラジアの症例の圧を測った経験があれば教え てほしい.2）Myotomie 後普段は陽圧帯があると思う が手術後はどの位の圧になるか。応答 1) 経験が ない. 2) Myotomie 後は入口部の圧低下がみられる が，○にはならないようである。

\section{当科における最近10年間の気道異物の統} 計的観察

○鳥谷龍三・小宗静男・笠 誠一・上村卓也 
（九大）

1976年から1985年迄の10年間当科を受診した気道異 物44症例について統計学的観察を行ったので報告し た. (1)年䕆的には $1 \sim 2$ 歳台に多く, 異物はピーナッ ツが多かった，(2)異物は右気管支に多く，特に硬性人 工加工物はほとんど右気管支にあった。(3)他科での気 道異物という診断率には向上が認められた。(4)摘出経 路はほとんどが上気道であった。摘出鉗子は万能異物 鉜子の使用が増加し，逆にロバート鉗子の使用が隇少 していた。（5)麻醉は全麻で摘出ロールは ventilation bronchoscope の使用がほとんどだった。

質問 調 重昭(福岡大). 鉗子は以前からあるロバートソン (キリアン) で十分であると思うが。またVentilation のロールはキリアン式ではないのか。応答 ご指 摘のごとく，スライド Jackson 式で，我々は混同して 使用していたようである. Ventilation 型でない，キリ アン式，ジャクソン式のことである。質問 野村 和(九州がんセンター). 症状分類のなかで無症状 2 例 の経過について，もう少し詳しく説明を。応答 1 つはマチ針でもう1つはクラウン（歯科用補緅物）で 西った。

\section{当科における acute epiglottitis 症例の検討}

○山口勝矢・大久保洋・平野 実 (久留米大)

Acute epiglottitis は, 小児に多くみら扢る緊急疾患 であり, その特徴として, 冬に多く, $2 \sim 4$ 歳の男児 に多い．起炎菌はインフルエンザ菌B型が多いなどが あげられる，今回1982年から1984年の 5 年間に当科に 扔けるAcute epiglottitis 患者, 14例について検討を加 えたところ，小児例は 1 例もなく平均年齢50歳で男性 に多い，李節差は成人ではあまりない, 症状は, 咽頭 痛, 嶼下障害から呼吸困難をきたすものが多い，所見 では全例に喉頭蓋腫脹を認める。細菌検查では静脈血 培養は全例陰性, 咽頭粘膜に $\beta$ 溶連菌, 肺炎桿菌を認め た，治療は抗生郕としてアンピシリンを多く用い，ス テロイドは全例に投与, 気管切開は 2 例に行った. 本 邦において小児例がなぜ少ないかは，現在推測の域を 越えないので, 今後本症例に遭遇したら, 血液培養, 咽頭培養, ウイルス抗体価などを検査し, 各施設の症 例を持ち寄り，系統的な調查と分析が望まれる。追 加上村卓也(九大).小児の急性喉頭蓋炎は最も注意 を要する小児疾患の一つであるが我々大学病院の耳鼻 科，小児科ではあまり経験がない，開業の先生は軽い 型の急性喉頭蓋炎を経験されれているであるうから今 後, 報告のあることを期待する。
副鼻腔原発の䯣外性形質細胞の 1 例

○大木啓子・吉田昭男・佐藤祐司・藤井哲郎

岡本 健（産業医大）

70歳男性の右副鼻腔に原発し，後に頚部に転移を認 めた䯑道外形質細胞腫の1例を報告した。腫浧は右上顎 洞，右篩骨洞に充満しており，一部眼窩内への浸潤も 認められた。病理組織所見では, H-E染色で形質細胞 のびまん性增殖が認められ, PAP 法による危疫組織学 的㭘查で IgA-K 型兔疫グロブリン産生の形質細胞腫 と誩断された。免疫グロブリン定量で IgA 高值を示 し, 血清免疫電気泳動でIgA-K 型M蛋白を認めた。 原 発巣に対し腫湟の可及的切除, 術後照射を行った。根 治的手術は本人が拒否したため行わなかった。その後 頸部リンパ節腫脹が出現したため, 右保存的頸部郭清 術施行. 転移が証明され, 術後照射を行った。治療後 も IgA-K 型M蛋白は持続しているが, 残存腫瘍の增 大，転移は認められていない。

\section{当科における昭和 61 年度死亡例の検討}

○是永克実・岡本 健・吉田昭男・永野隆治 麻生裕明 - 佐藤祐司 - 知念信雄（産業医大）

昭和61年 1 月から 12 月までに当科に扔いて死亡退院 となった症例は12例で，すべてが悪性腫瘍患者であっ た。これは，同期間の当科成人入院患者数 296 名の 4.1 \%に当たり，悪性腫演患者77名の $15.6 \%$ に相当した。 12 例中 2 例 $16.7 \%$ に病理解剖が行われた。疾患別にみ ると, 下咽頭癌が 4 例と最も多く, 続いて上罰癌, 舌 癌が各 2 例, 中咽頭癌, 歯肉癌, 頸部腫瘍, 甲状腺癌 がそれぞれ1例であった。初診時の TNM 分類が確認 できたものは10例で，T3が 3 例，T3が 6 例，T4が 1 例，M流すべて0であった。臨床病期分類では，II期 が 1 例，III期が 6 例，IV期が 3 例で，10例中 9 例がIII 期以上と進行例が多くみられた。病理組織学的分類で は，11例が扁平上皮癌で，1例が低分化型甲状腺癌で あった。扁平上皮癌のうち 3 例が高分化型， 3 例が中 等度分化型， 3 例が低分化型であった，症例の再検討 を通じ, 悪性腫瘍の治療の難しさ, 覀性腫湯患者の全 身管理の難しさ，早期発見の重要性が感じられた。 質問 小宮山荘太郎(九大), 下咽頭癌症例の母数はど の程度か. 応答 今まで tumor free となった症例 はなく，全例が死の転帰をとったことになる。質 問 平野 実(久留米大).12例の中で振り返ってみて, この病気はこう治療していればよかった。あるいはこ ういうことに注意していればよかったということがあ れば教えてほしい。

応答 岡本 健. 死因につい 
て毎年検討し反省している.下咽頭癌についてはなお， 手術成績が思わしくない. 今後に検討して行きたい. 当科における上顎悪性腫湯の統計的観察

○郭 健稔・池間晶毅・小川雄司・江浦重治 加藤寿彦・曾田豊二（福岡大）

昭和 49 年から昭和 61 年までに当科で，治療を行った 左上䫑悪性腫瘍患者68例で，50歳台から70歳台で全体 の70\%を占めていた。性別では, 男性に多く男女比は, 1.5：1であった。主訴は, 煩部腫脹が最も多く, 次い で鼻閉，煩部痛の順であった。扁平上皮癌 2 次例 54 症 例につき，JJC 案に基づきその進展度をみてみると， Stage II, IIIで全体の $90 \%$ を占めていた. 扁平上皮癌 1 次例 54 症例中, 手術を行った 45 例の 5 年累積生存率は 59\%であった。質問 野村 和（九州がんセンタ 一).1）手術症例の主たる術式を.2）全症例54例の累 積生存率は。応答 1) 累積生存率が手術例(45例) 全体で59\%と高いのは, T2T3例にも初診時に帰って, 全摘，拡大全摘をほとんどの例に施行したためと考え る. 2） 1 次例 54 症例の生存率は, 手術日を治療開始日 としたので，今回は検討していない。質問 小宮 山荘太郎 (九大). 生存率の件だが, 粗生存率 (単に何 列治療して, 他因死も全部含めて何人亡くなったか, 何人生存しているか）は, 単純に出してみるとどれく らいか. 応答 手術施行した 45 症例 $\mathrm{T} 1$ で粗生存 率, $100 \%, \mathrm{~T} 2 \mathrm{~T} 3$ で約 $40 \%, \mathrm{~T} 4$ は, 1 年以内に死亡し ている.

\section{予後からみた持続動注・放治併用 147症例の検討}

○野村 和・山下弘之・田中裕子・好田隆是 山崎恵三・工藤庄治・松嶋四郎・松村祐二郎 (九州がんセンター)
1972年 3 月〜1986年12月までに口腔がん，上・中咽 頭がん，上顎がんは430例である.このうち 1 次症例 327 例に対して135例に，また 2 次症例103例中12例の計147 例に持続動注・放射線の併用治療がなされた，上咽頭 がん36例では動注 5 年累積生存率 $66.7 \%$, 非動注 40.1 $\%$, 中咽頭がん $49.1 \%$ と $44.5 \%$, 上顥がん $34.1 \%, 33.4$ \%であった．舌がんでは非動注 $59.2 \%$ ，動注 $38.9 \% て$ St I ・IIにラジウム治療を施した症例がほとんどで後 者によい結果を得た. 動注薬剤の選択では $5 \mathrm{Fu}, \mathrm{BudR}$ を比較すると, 舌がん, 症例では BudR, 上䫕がん症例 では $5 \mathrm{Fu}$ がやや優っているが大差と認めない. 対象と した症例での血管の選択が最重要な問題であると思わ れるが局所支配の血管を選択するよりも腫崵進展形態 を考慮すると頭頸科領域では, 外頸動脈への infusion すなわち分岐部へのカテーテル設置の方が望ましいと 思われた。質問 曾田豊二(福岡大)。基本的には， 選択的に動脈を選んで, 動注するには，いろいろな根 拠がある。しかし，その基部，外頸動脈に行うとよい というのは, 興味深い, それは, 持続動注の関連での 結論か. 応答 One shot 動注の経験が余りないの で比較が出来ないが動注法はいずれであっても，腫場 を含めた支配動脈を選択することに差はなく， ascending pharyngeal arteryを含めた方がいずれの方法で もよいのではないかと考えている。質問 小宮山 荘太郎 (九大)。抗腫湟剤の脳細胞に対する影響はどの 程度分かっているのか. 応答 ご指摘の点が一番 大きな問題点である. BudR 単独であると脳腫潢治療 のために開発された薬品であるので無難である。しか し, 他の $5 \mathrm{Fu}, \mathrm{PEP}, \mathrm{BLM}$ など罧剤については内頸動 脈を含めた注入は考慮すべきと考える。

\section{第13回滋賀県地方部会}

昭和62年 4 月 29 日（水）一守山市野洲郡勤労福祉会館

\section{ベンチレーションチューブの選択と留置期間} 駒田一朗（滋賀医大）

小児渗出性中耳炎におけるベンチレーションチュー ブ捙入について検討した。 ベンチレーションチューブ の形態によりチューブを分類し，その留置存続期間を 比較した. 内側フランジの大きなパパレラII型チュー ブは約 1 年 3 カ月と最も長期にわたり存続した。千ュ
ーブが脱出したあとの再燃は約 $2 / 3$ の症例に認められ， 再燃例の平均留置期間は約10力月であった。長期留置 の目的にはパパレラ II 型チューブが優れている.

質問 山道 至 (近江八幡市民)。1）チューブの閉塞 の有無は如何にして決定しているか.2）水泳は禁止し ているか. 3) チューブは高価なので, 全例にベンチレ ーションチューブを插入するのは如何か. 
の発症，特に骨新生を来すような悪影響を与えるので はないかとの考えがあるので，これについて検討し， 手術年齢と関連が少ないとの結論を得た。

最近 1 年間の興昧ある頭頸部腫瘍症例について 山道 至（近江八幡市民）

昭和 61 年 5 月から 62 年 4 月までの 1 年間に当院で扱 った頭頸部領域の腫湯のうち比較的頻度が少ない疾患 で興味ある知見を得た症例について報告した。右外眼 筋麻瘏を合併した甲状腺癌症例（follicular adenocarcinoma)で手術後に 3 力月間続いていだ右外眼筋麻㽻 が治癒した65歳女性症例。下咽頭癌 (T3 N1 M0) で術 前の血管撮影で左霄大網動脈の血流がそしいために胃 管作製岋不適当と判断し，咽喉食摘後の再建に大筋胸 皮弁を用いた症例.耳下腺深葉腫瘍の手術には顔面神 経保存のために蹎微鏡を使用し鼓室形成用手術器具が 有効であった４歳女見の上咽頭奇形腫を軟口蓋の緃 切開を施行せずに明視下で摘出した，以上 4 症例につ いて娭討し報告した。質問 北野真由美。テラト 一マ症例の聴力, 鼓膜所見, ティンパノメトリ一所見 について。応答 聴力は両耳とも正常，ティンパ ノグラムは両耳共A型であった。

\section{下㸶頭癌 21 症例}

○大田耕造・佐藤佳代子・広瀬章子・東 文生 (大津赤十字)

Plummer Vinson 症候群より輪状後部癌八進展した 症例を文献的考察を加え報告した。症例は50歳女性。 主訴は咽頭痛で，昭和61年 3 月より近医内科で加療さ れ，貧血の治療を続けていたが，䁩下困難傾向がある ので当科へ同年 7 月紹介された，食道透視で web 認 め, sideroperic anemia も強いので造血剤を投与し症 状の軽快をみたが 2 力月後, 披裂部の潰湟を生じ, 試 切にて分化㤠扁平上皮癌の病理診断であった。 T2 N0 M0 で放射線 4000rads, 化学療法後, 咽喉食剔を施行 しDPflapにて食道形成を行った。下咽頭癌の早期診 断は困難であるが, 詳細な問診・食道透視の重要性を 強調した。質問 山道 至. DP flapにて再建され た理由について。応答 術前に施行した ${ }^{60} \mathrm{Co}$ 及び 化学療法が著効であり, 食道透視上, 及び術中所見で DP flap 使用を決定した。追加网本康比古Ｔ２ 症例に颁部切開咽頭開放により, $\mathrm{Co}_{2} レ$ レ゙ーの反復 使用と照射治療を施行した 8 症例を追加した。咽喉頭 食道機能の保存が容易で試切拀上び追加治療が経過観 察中可能で繰り返すことができるので追試をお願い致 したい. 応答 今後, 下咽頭瘻について検討して
いきたい. 質問 北嶋和智(滋賀医大).PVSの診 断から SCC の発症までの期間が 2 力月短いか。 応答 PVSより SCCへの経過期間に関しては長期間 と文献上にはあるが正確なデー夕はわからない。ただ 病悩期間は $1 \sim 3$ 力が多いとされ，下咽頭癌の進行 は6力月内に急速とされている。

\section{音声基本周波数の $\mathrm{AC} / \mathrm{DC} \%$ におよぼす影響} 北嶋和智（滋賀医大）

熱線流量計を用いた $\mathrm{AC} / \mathrm{DC} \%$ 值は有効な喉頭機能 検査法である，本報告では音声ピッチの検査成續にお よぼす影響についてのべた。(1)8人の正常人に音圧を 一定に保ちながらピッチを上昇させると $\mathrm{AC} / \mathrm{DC} \%$ は 有意に上显を示す。ただし不自然に高いピッチになる と急激に低下を示す。(2)日常の検査では楽なピッチで 発声させて，3回のトライアルの平均をもって検查成 績としているが,この時のピッチ変動に由来する AC/ $\mathrm{DC} \%$ の変動は病的例と正常例の差異に比べれば十分 に小さい.(1)，(2)の結果加ら AC/DC\% は極端に高いピ ッチを指定しないがきり分に信頼出来る検查方法と 言える. 質問 東 文生 (大津赤十字)，1） AC/ DC\%が40\%位で聴覚印象の良い症例もあるが，これ について．2）検査時患者に何らかの指示を行って，上 手に発声させるようなテクニックを行っているか. 応答 1) $\mathrm{AC} / \mathrm{DC} \%$ はる短時間内での值を示すの でこのためと考える，2）特に練習や指示は与えてい ない。ただし極端に高い，または大きい音声で発声し ている場合は直させる。

\section{錐体外路系様症状を呈した喉頭神経症} 和由耕篤（水口町）

昭和59年の 1 例で昭和47年生男子12歳。喉頭異常感 及び前頸筋，口腔周囲筋の不髄意運動及びセキバライ が主訴で頸部はあたかもエリマキトカゲ様であった。 $2 \sim 3$ 分は中止出来るが 5 分とは止めていられなかっ た。滕蓋腱反射 $($ 一)辠丸反射 $($ 一)腹壁反射 $($ 一) 二ス夕 グムスは認めるが方向不定で判定し難い，喉頭及び咽 頭は異常と認めなかった。その他特記す心゙き症状はな かった。ダーゼン $5 \mathrm{mg} 3 \mathrm{~T}$, セルシン $2 \mathrm{mg} 3 \mathrm{~T}$ ，ナウゼ リン $3 \mathrm{~T}, 3$ 日分で $90 \%$ 自覚症状は改善され，8日分て 完全治瘜した 1 例である.上記のごとき反射の消失や, 頸部筋肉の不随意運動8日分の投薬で治癄するとは考 えられず，喉頚神経症に伴った随伴症状と考えた。 質問 東 文生(大津亦十字)。大変與味ある喉䫒異常 感症の症例であるがこのような例には心理テスト（例 えば梁町のCMI 等)を行う必要があるのではないか。 
応答 喉頭神経症に対する他のテストについては開業 医で 1 人でやっている訳で 1 日，百数十名の患者の合

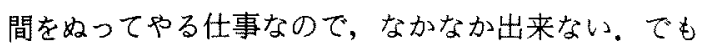
今後できるだけ種々の検查も取り入れて実施したいと
思う。

招待講演

外リンパ瘦について

竹田泰三(高知医大)

\section{第12回鹿児島県地方部会}

昭和62年 4 月 26 日（日）一鹿児島大学医学部第 4 講義室

\section{耳下腺管異物の 1 例}

O内溒明裕・深水浩三・古田 茂（鹿大）

我々は最近, 爆発事故に際して飛散した小石片が耳 下腺管を閉塞し, 年余にわたって耳下腺の反復性炎症 をきたした極めてまれな症例を経験したので報告し た. 症例は 50 歳男性で, 発症は, 昭和 55 年であり, そ の後 6 年間にわたって右耳下腺部の反復性腫脹と疼痛 をきたした。当科にて手術を施行したところ，右耳下 腺管を閉塞する小石片が剔出された。術後の詳しい問 診の結果, 40年前に遭遇した爆発事故の際の破片が, 右㛲部を貫通して耳下腺管内に留まったものであるう と推察された。質問・追加松村益美（鹿児島市 立).CT-SCANを行ったか. 行っていれば術前に診断 がついたと思う。応答 CTは行っていなかった。 䓄問 朝隈真一郎(鹿児島市)。異物を摘出後, 耳下腺 管の処理はどのようにしたか。応答 手術時は異 物除去後, 異物より末梢の耳下腺管内の乾酪様物質を 可及的に除去し，術直後から肉芽抑制のためにアゼラ スチンの投与, 1 週間後より涙管プジーによる耳下腺 管のブジーを行った．質問 勝田兼司（国立南九 州中央). 術後, 特に最近の耳下腺機能検查を施行して いるか. 応答 術後約 1 力月に耳下腺造影を行い, 狭䂟は残存して扔り腺実筫の描出は不可能であった。 しかし現在まで同部の腫脹はなく経過良好である。

巨大な耳下腺混合腫瘍を有した鼻副鼻腔原発

悪性リンパ腫, 膵, 甲状腺癌患者の剖検例

○飯田冨美子・奥村晃久・村野健三・昇 卓夫 (鹿大)

右耳下部腫㾮, 顔面腫瘍を医家的治療なしに療養し， 全身衰弱をきたした症例の剖検例を報告した，主要病 変として(1)耳下腺混合腫湟：50年以上の経過をもち $33 \times 25 \times 27 \mathrm{~cm}(30 \mathrm{~kg})$ 以上の腫瘤, (2)鼻副鼻腔から眼 筥, 硬口蓋に浸潤した悪性リンパ腫, 左頸部リンパ節
及び肝転移: 組織構造は diffuse, medium cell type, (3)膵島細胞癌 $(3 \times 3 \mathrm{~mm})$ 及び肝転移 $(5 \times 5 \mathrm{~mm}):$ in sulinoma と推定，(4)左甲状腺硬化癌，(5)上皮小体腺腫 等々が確認された。(3)(4)(5)は剖検にて判明したものて 多発性内分泌腫症 (MEN1) の範疇に入るものと思わ れた。質問 伊東祐久(鹿児島市)。症例の住所は どこか。また 1 人暮らしであったか。応答 鹿児 島市下福元町に住んで扔り，娘が看護していた。

橋本病に合併した甲状腺癌の 1 例

○上野員義（県立鹿屋）

鶴丸浩士・福田勝則（鹿大）

橋本病に甲状腺癌を合併した 1 例を経験したので報 告した，患者は65歳女性，右葉上極と左葉下極に大小 の硬い腫瘤を触知し，X線上，粗大顆粒状の石灰化を 認奴。マイクロゾームテストのみ陽性であった。右 葉切除を行い, 病理学所見では, 乳頭癌と, 肧中心を 持った著明なりンバ球浸潤のみら机る橋本病の合併と 診断された。文献上，橋本病に甲状腺癌の合併は，約 $10 \%$ 前後あるとされている。橋本病で甲状腺が結節状 に触知され，X線上石灰化が認められる時は，癌の合 併を念頭において治療すべきことを強調した。

体位と耳管開閉能に関する研究 大野文夫（鹿大）

体位による耳管機能の変化を明らかにするために, 音響耳管機能検查法を用いて 6 体位（座位・背臥位・ 腹臥位・左右側臥位・ヘッドダウン)における嚥下に 伴う耳管開閉能及びバルサルバ法による耳管開閉能を 測定した. 結果 1 ．矒下に伴う耳管開閉能,バルサル バ法による耳管開閉能いずれも座位と比較して，水平 位,ヘッドダウンでは低下した，2．側臥位では，上向 き耳の方が下向き卡り開放率が高い.3.これらの変 化は, 静脈圧上昇による粘膜の肥厚が原因であると推 論した。質問 清田隆二(鹿大). lateral up, lateral 